\title{
Impact of mire reclamation on export potential and characteristics of dissolved carbons in the Sanjiang Plain, Northeast China
}

\author{
Y. D. Guo ${ }^{1}$, C. C. Song ${ }^{1}$, Y. Z. Lu ${ }^{1}$, Y. Y. Song ${ }^{1}$, and Z. M. Wan ${ }^{2}$ \\ ${ }^{1}$ Key Laboratory of Wetland Ecology and Environment, Northeast Institute of Geography and \\ Agroecology, Chinese Academy of Sciences, Changchun 130012, China \\ ${ }^{2}$ College of Earth Science, Jilin University, Changchun 130061, China
}

Received: 14 March 2012 - Accepted: 10 April 2012 - Published: 7 May 2012

Correspondence to: C. C. Song (songcc@neige.ac.cn)

Published by Copernicus Publications on behalf of the European Geosciences Union.

\section{Abstract}

As an important dissolved organic carbon (DOC) reservoir, the mires in the Sanjiang Plain, Northeast China, have been suffering from large scale of reclamation, and thus elevated loss and degradation since the 1960s. This study compares the export dy5 namics of the dissolved carbons, as well as the chemical characteristics of DOC, in the natural mire, degraded mire and drainage ditches during the growing seasons from 2008 to 2010 with the aim to clarify the final effects of the longterm reclamation on the export dynamics of the dissolved carbons. Results show that the average concentrations of total dissolved carbon (TC) and DOC are much higher in natural

10 mires than that in degraded mire and drainage ditches. The DOC concentration for natural mires, about $35.53 \pm 5.15 \mathrm{mgl}^{-1}$ on average, is nearly 2.39 times of that in degraded mire $\left(14.84 \pm 4.21 \mathrm{mgl}^{-1}\right)$ and 2.77 times of the average value in ditches $\left(12.84 \pm 4.49 \mathrm{mgl}^{-1}\right)$. Similarly, the hydrophobic fraction and $\mathrm{SUVA}_{254}$ of DOC also represent lower values in the degraded mire and ditches, which suggests that mire

15 reclamation has resulted not only in the reduced DOC concentrations but also in the reduced chemical stability. Whereas the inorganic dissolved carbons (DIC) exhibits obvious increased trends in drainage ditches in comparison to natural mires. Analyses of exitation-emission fluorescence spectra reveal that the reclamation has greatly altered the DOC composition with more biological organic substances exporting from the Sanjiang Plain. The presence of protein- and tryptophan-like substances in the ditches indicates there has been extensive agricultural pollution in the surface waters. Changes in the hydrological regime of the mire landscapes by sustained agriculture activities are deemed the prodominant reason, and the trends in the export dynamics of dissolved carbons will keep on if mire reclamation continues in the future. 


\section{Introduction}

The global transport of organic carbon by rivers to the oceans is estimated to be $0.36 \mathrm{Gt}$

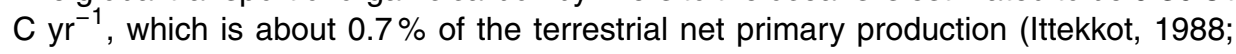
Aitkenhead and McDowell, 2000). The flux represents only a small part of components

5 of the global carbon cycle, but it play an important role in many ecological processses in the estuarine and coastal systems. It helps to control the mobilities of pollutions as trace metals and hydrophobic organic componds (Bhatt and Gardner, 2009), the rates of many photochemical reactions (Williamson et al., 1996), the attenuation of UV radiation (Gao and Zepp, 1998), and most of important, the processes of marine

10 primary production (Raynond et al., 2000) and the rate of terrestrial carbon burial (Goñi et al., 1998).

During the past decade, the role of boreal wetlands in regional and global carbon budgets has received an increasing amout of attention for being recognized as a huge pool of soil carbons and dissolved organic carbon (DOC) to the nearby fluvial ecosys-

15 tems (Worrall and Burt, 2008). Increases in the concentration of DOC in surface water are widely reported in sub-boreal settings with wetlands (Driscoll et al., 2003; Hejzlar et al., 2003; Worrall and Burt, 2008). Several reasons to explain the observed increases have been porposed including increasing temperature (Freeman et al., 2001), occurrence of severe drought (Worrall and burt, 2008), change in the amount of stream

20 flow (Tranvik and Jansson, 2002), and increase in atmospheric depostion (Evans et al., 2005). In spite of the numerous studies, the predicts of future DOC fluxes from northern wetland watersheds result in both increase (Clair et al., 1999) and decrease (Moore et al., 1998; Pastor et al., 2003), owing to anticipated hydrological conditions. Regardless of the contray results, it could be concluded that boreal wetlands are indeed much sen-

25 sitive to climate changing and human activities in the export potential of DOC, for they usually store huge quantity of carbon formed in the historical period.

Land-use change represents the most powerful alteration of the terrestial ecosystem in the past 300 years (Vitousek et al., 1997). However, the influence of land-use change

$$
5349
$$

on DOC dynamics is still largely uncertain especially in boreal wetlands area, although it has been reported that agricultural plantation could increase the export of other nutrients such as nitrogen and phosphorus to fluvial ecosystems (Mander et al., 2000; Tang et al., 2011). The production and delivery of DOC in the wetlands are mostly 5 determined by the hydrological conditions which would be intirely altered by land-use change (Wagner et al., 2008; Worrall et al., 2008; Wilson and Xenopoulos, 2009). Following the alteration, the mineralization processes of soil carbon would change correspondingly and break the balance of the output fluxes between $\mathrm{CO}_{2}$ and $\mathrm{DOC}$ in the end (Hernes et al., 2008). A significant threat to the hydrological regime associ10 ated with land-use change is artificial drainnage in the mires. In UK blanket peatlands, drainages were introduced to draw down the water table to improve the productivity of the grazing grass (Holden, 2004), and besides of several negative environmental problems, the changes of DOC dynamics resulting from the drainages have been observed in some of the catchments (Wallage et al., 2006). Drains blocking and afforestation ac5 tivities after drainage diging were the important factors affecting DOC concentrations in the surface waters (Wallage et al., 2006). Land use and management activities, which vary markedly over small distances and change over short time periods, are main candidates to the increase in DOC export over the recent past (Yallop and Cluterbuck, 2009; Clark et al., 2010). Changnon and Demissie (1996) concluded the changes in

20 land use and drainage have play a more important role than changes in precipitation in increasing stream peak flow events and hence the DOC fluxes over the past 50 years in North America. But wetllands in different regional climate and hydrological managements have disparate performances in DOC production and exportation, which results in difficulty to draw a universal conclusion.

The conclusions above, however, mainly come from the surveys in Europe countries and North America, and limited studies have been reported in North China, where exists large area of mire-wetlands especially in the Sanjiang Plain. In the Sanjiang Plain, the area of freshwater mires had amounted to $35260 \mathrm{~km}^{2}$ in the $1960 \mathrm{~s}$, covering $32.7 \%$ of the total area of the plain. But since the 1960s, the large scale of mire reclamation 
to paddy fields has led to the amazing shrinkage to $9600 \mathrm{~km}^{2}$ in 2005 to guarantee the food security of China. The dramatic loss and degradation of natural mires had greatly changed the export dynamics of the dissolved carbons produced from the organic soil accumulating in the mires for thousthands of years. Moreover, the natural hydrological

5 regimes of mires and rivers were altered entirely by the drainage building to flood discharging, with the length reaching up to $2.55 \mathrm{~km}$ per square kilometer on average in 2010. Hence, the large tracts of mires avoiding to be reclaimed were also degraded seriously owing to hydrological disturbance. As a result, the great alteration in the export potential of DOC from the Sanjiang Plain is ineluctable, which could directly alter

10 the carbon fluxes to the Amur River and even the Sea of Okhotsk in the northwest of North Pacific, as the Sanjiang Plain is located in the Amur River Basin, the world's ninth longest river.

But by now, to what extent the DOC fluxes has been altered by the mire reclamation and drainage ditch building is still unkown, and the variation in the characteristics of

$15 \mathrm{DOC}$ is also eager to be surveyed to estimate the possible consequences to the lower aquatic ecosystems. Therefore, the objectives of this study are to (1) determine the impacts of mire reclamation on the fluxes and export potential of the dissolved carbons by contrastive field measurements in the natural mire, degraded mire and artificial ditches in the Sanjiang Plain, (2) investigate the alteration of the chemical components of DOC 20 released from the different landscapes above.

\section{Materials and methods}

\subsection{Site description}

The Sanjiang Plain is located in the winter-cold zone in Northeast China and is formed by the three major rivers of Amur, Ussuri, and Songhua. Boreal climate conditions and

25 low slope grade make it the largest mire concentration in China (Fig. 1). The plain experiences a mean annual temperature of $1.9^{\circ}$ and a mean annual precipitation of 5351

$565.3 \mathrm{~mm}$. The coldest month occurs in January with $-19.8^{\circ} \mathrm{C}$ and the warmest in July with $21.6^{\circ} \mathrm{C}$ (1981-2008). The surface water and soil are completely frozen from late October to the next April, and begin to melt in late April. Plants in the natural mire, mainly Carex, Deyeuxia angustifolia and Betule fruticosa, burgeon during the 5 end of April and wilt in mid-October. In the mires, it is covered by gleying swampy soil whose organic contents usually exceed $15 \%$ in the upper $50 \mathrm{~cm}$ layer with albic soil underneath, and large area of peat could often be found in the mires.

\subsection{Field sampling}

Sampling campaigns were carried out during the growing seasons from 2008 to 2010 .

10 To determine the impacts of different strength of mire reclamation on the dynamics of dissolved carbons, three types of mire-related landscapes, including undisturbed natural mire, degraded mire and artificial drainage ditches, were chosen to collect water samples. The sampling sites for the undisturbed natural mire were chosen at the experimental fields of the Sanjiang Mire-wetland Experimental Station, Chinese Academy of

15 Sciences $\left(47^{\circ} 35^{\prime} \mathrm{N}, 133^{\circ} 31^{\prime} \mathrm{E}\right)$. In the experimental fields, two types of pristine freshwater mires were chosen including the seasonally-waterlogged mire (SLM) with Calamagrostis angustifolia as the predominant vegetation and the perennially-waterlogged mire (PLM) with Carex lasiocarpa. The mires developed in round depressions and had nearly no output runoff except in extreme rainfalls. They have experienced no distur-

20 bance from human activities and are good references as pristine mires before reclamation. In each mire, four surface water samples were collected along the straight line across the mire when sampling. The sampling site for the degraded mire (DGM) was chosen at the old river course of Bielahong River along which large area of mires were preserved. But the hydrological blocking of the artificial dithes nearby and 25 partly mire reclamation in the catchment had led to extensive degradation, as the surface content of soil organic matter declined from $131.66 \pm 19.21 \mathrm{mg} \mathrm{kg}^{-1}$ in 1980 s to $91.25 \pm 25.07 \mathrm{mg} \mathrm{kg}^{-1}$ in 2008. Simultaneously, water samples from drainage ditches of three hierarchies (arterial drainage ditch (A-DD), branch ditch (B-DD) and capillary 
ditch (C-DD)) were collected in Bielahong Ditch, the largest drainage system in the Sanjing Plain, in which the water volumes come mainly from the surface runoff and discharge from paddy fields covering the the majority of our study region (Fig. 1). For the three types of landscapes, water samples were collected synchronously every ten days

5 from beginning of May to late October. When sampling, standard 3I samplers made of synthetic glass were used for the surface water, and $300 \mathrm{ml}$ surface water samples for a site was hold in glass vials and preserved in $4^{\circ} \mathrm{C}$ for further analyses.

\subsection{DOC concentration and fractionation}

Collected water samples were filtered through $0.45 \mu \mathrm{m}$ filters into separate vials, and 10 then analyzed for DOC, total dissolved carbon (TC) and inorganic carbon (DIC) with DOC analyzer (C-VCPH, Shimadzu, Japan). TC was measured by high-temperature combustion. DIC was detected after sample acidification by $25 \% \mathrm{H}_{3} \mathrm{PO}_{4}$ and $2 \mathrm{moll}^{-1}$ $\mathrm{HCL}$ and transformation to $\mathrm{CO}_{2}$, and DOC equals TC minus DIC.

To determine the hydrophilic and hydrophobic fraction of DOC, water samples were

15 pumping through glass columns filled with Amberlite XAD-8 resin. The column effluent contains the hydrophilic fraction of DOC (HiDOC), whereas the so-called hydrophobic fraction of DOC (HoDOC) sorbs to the resin and (Raastad and Mulder, 1999). Before use, the XAD-8 resin was cleaned with methanol, acetonitrile and diethyl ether in a Soxhlet extractor. Then the resin was packed into glass columns with an inner diame20 ter of $0.7 \mathrm{~cm}$ and a resin volume of $10 \mathrm{ml}$. After packing in columns, it was extensively rinsed with ultrapure water, methanol, $0.1 \mathrm{M} \mathrm{NaOH}, 0.1 \mathrm{M} \mathrm{HCl}$ and finally with ca. 25 void volumes of ultrapure water during $24 \mathrm{~h}$. During fractionation, the $\mathrm{pH}$ of water samples was adjusted to 2.0 at first. Then pumps were used to keep the effluent rate at $0.6-0.7 \mathrm{ml} \mathrm{min}^{-1}$. The DOC in column effluents, namely HiDOC, was measured with

25 the DOC analyzer directly, and HoDOC is calculated as total DOC minus HiDOC (Simonsson et al., 2005).

5353

\subsection{Special absorbance and three-dimensional fluorescence measurement}

SUVA $_{254}$ has been suggested as an index of the aromaticity of DOC and changes with differeneces in the chemical composition of DOC (Peichl et al., 2007; Jonesa et al., 2009). SUVA 254 is defined as the UV absorbance at $254 \mathrm{~nm}$ divided by the DOC 5 concentration measured in milligrams per liter $\left(\mathrm{mgl}^{-1}\right)$, and is reported in units of $\mathrm{Img}^{-1} \mathrm{~m}^{-1}$. UV measurements was made on a a UV-7504 spectrophotometer using $1-\mathrm{cm}$ quartz cells with Milli-Q water as the reference.

To identify and compare the composition of DOC in the landscapes, threedimensional excitation-emission matrix (EEM) fluorescence for the samples on 20 July 10 was measured using a Hitachi F-7000 fluorescence spectrometer (Hitachi High Technologies, Tokoy, Japan) with a 700-voltage xenon lamp at room temperature. The scanning ranges were $220-400 \mathrm{~nm}$ for exitation and $250-500 \mathrm{~nm}$ for emission, and the bandpass widths were $2 \mathrm{~nm}$ for both excitation and emission. The effect of Water Raman scatter was eliminated by subtracting a Milli-Q water blank of the EEM. The 15 spectra were corrected for instrumental response according to the procedure recommended by Hitachi (Hitachi F-7000 Instruction Manual). Then, the EEM was corrected for absorbance by multiplication of each value in the EEM with a correction factor to eliminate the inner-filter effect, based on the premise that the average path length of the absorption of the excitation and emission light was $1 / 2$ of the cuvette length (Singh 20 et al., 2010).

\subsection{Statistical analysis}

The softeware SPSS 11.5 was used for statistical analyses. The differences in DOC, TC, DIC and SUVA ${ }_{254}$ in the surface waters from different landscapes were tested by the method of ANOVA. When $P<0.05$, the comparisons or the factor tested were 25 considered statistically significant. By the way, to quanify the seasonal variation of the dissolved carbons and SUVA 254 , the coefficient of variance $\left(C_{\mathrm{V}}\right)$ was introduced as the index. 


\subsection{Concentrations of dissolved carbons in the landscapes}

As shown in Fig. 2, there are significant differences in the mean concentrations of dissolved carbons among the three types of landscapes during the three years. For

5 TC, the mean concentrations in the natural mires, namely, SLM and PLM, are significantly larger than those in the degraded mire DGM or in the drainage ditches. The average TC concentrations are $37.99 \pm 5.31,24.61 \pm 5.73$, and $23.34 \pm 6.25 \mathrm{mgl}^{-1}$ for SLM and PLM, DGM, and the ditches, respectively. The DOC concentration for PLM and SLM, approximately $35.53 \pm 5.15 \mathrm{mgl}^{-1}$ on the average, is nearly 2.39 times that in 10 the DGM $\left(14.84 \pm 4.21 \mathrm{mgl}^{-1}\right)$ and 2.77 times of the average value in C-DD, B-DD, and A-DD $\left(12.84 \pm 4.49 \mathrm{mgl}^{-1}\right)$. Statistically, the DOC concentrations are highly positively related to TC in SLM, PLM, and DGM for all the years $(P<0.05)$, whereas the relation between DIC and TC appears closer only in the ditches from A- to C-DD. As for the concentrations of DIC in DGM and ditches, the averages 9.82 and $10.52 \mathrm{mgl}^{-1}$ are

15 both significantly higher than in the natural mires where the mean value of DIC is only $2.38 \mathrm{mgl}^{-1}$ throughout the three growing seasons.

Noticeably, from C-DD to A-DD, the concentrations of DOC, TC, and DIC all decline gradually. TC mean concentration has changed from 28.63 to $19.46 \mathrm{mg}^{-1}$ with a decline proportion of $32.0 \%$. DOC has declined by $23.42 \%$ (from 14.69 to $11.25 \mathrm{mg} \mathrm{I}^{-1}$ )

20 and DIC by $41.74 \%$ (from 13.99 to $8.15 \mathrm{mgl}^{-1}$ ). So, the decrease of TC resulted mainly from the change of DIC. In the natural waters, DIC is mainly in the form of $\mathrm{CO}_{3}^{2-}$ and dissolved $\mathrm{CO}_{2}$, which are prone to be released from the surface water because only small changes in $\mathrm{pH}$, temperature, and metal ion content in the water act effectively on their loss (Ortega etal., 2005; Atekwana and Fonyuy, 2009). Besides, part of DOC is

25 very sensetive to UV light when transported in the courses, especially with low water levels like the ditches in our study (Tue-Ngeun et al., 2005). It could be the persuasive reasons for the decreased dissolved carbons as related research in the same area illustrates (Wang et al., 2010).

$$
5355
$$

In Fig. 2, no apparent differences in the seasonal trends of the dissolved carbons among the three landscapes can be clearly observed. For all the sites, there are usually more than one concerntration peaks occoured during one growing season. In SLM and PLM, TC and DOC concentrations represent the prodominant peaks usually in 5 late spring or late summer. In the DGM and ditches, there are two concentration peaks which emerge annually in June and September, which is very similar to the drainage ditches. It seems that there is no direct relationship between air temerature and carbons' concentration. But Guo et al. (2010) conclude that the linear correlation between temperature and DOC/TC concentration only exists before mid-summer in the same 10 natural mires. In our study, the dynamics of standing water level seems more meaningful in the scale of whole growing season. In SLM and PLM, it can be clearly identified of the dramatic decline of DOC/TC concentrations with the drawdown of the standing water level in 2008 and 2010 (Fig. 3). Likewise, the concentration peaks in the DGM and ditches also have close relationship with the dynamics of water level. But, it appears

15 that most of the water level peaks, representative of runoff events, are usually coincident with the concentration troughs of DOC and TC through the three years. Hence, it can be concluded that the dilution effect of runoff event is likely predominant over the transport process for the dissolved carbons in the DGM and ditches. Hydrological regime is the most important factor controlling the export dynamics of the dissolved

20 carbons coupling with seasonal temperature change. Worrall et al. (2008) indicates that the frequency of rainfall events is the key factor in controlling DOC flux and concentration in catchments with peat soils. In DGM and ditches, the clearly concentration troughs in late summer may result from the high frequency of rainfall events in early days which limit the accumulating processes of DOC in the soils.

25 Furthermore, the seasonal variability of the dissolved carbons exhibits great disparty among the three landscapes. In the ditches, the $C_{\mathrm{V}}$ for TC, 0.45 on average, is apparently larger than that in SLM, PLM, and DGM which only reach $0.33,0.28$, and 0.31 correspondingly. As to DOC, the $C_{\mathrm{V}}$ values exhibit the same trend to TC, which proves indirectly the significance to pay more attention to DOC in our study. The largest $C_{\mathrm{V}}$ 
values in the ditches come from the voilent fluctuations in runoff through the growing season. As shown in Fig. 3, the runoff processes in the ditches are much more short-lived and high-undulated as compared with DGM which possesses nautural river course and catchment. The long-term mire reclamations, performed based on the de-

5 mand of dredging floods as quickly as possible, have inevitably resulted in the susceptibility of runoff regime to rainfall events. But in fact, the escaped mires, like DGM, even SLM and PLM, are also inevitably impacted by agricultural reclamation, for the alteration has resulted in synthetical affection on the hydrological regime in the whole Sanjiang Plain (Li et al., 2007).

As our sampling design, the dynamics of dissolved carbons in PLM and SLM provide a reference backdrop that there is no impact of mire reclamation. According to the results above, the reclamation from natural mires to degraded mires and the paddy fields has greatly lowered the export concentrations of DOC and TC to the river systems but increased DIC concentration. Moreover, the building of drainage dithches has led

15 to more violent seasonal fluctuations of the dissolved carbons.

\subsection{Fractionation and SUVA 254 of DOC}

Apparent distinctions in the concentrations and seasonal trends of DOC fractions, Hoand $\mathrm{Hi}-\mathrm{DOC}$, for the three landscapes are observed in Fig. 4. Ho-DOC in natural freshwater is generally composed of humus and coacervates with large molecular weight, whereas Hi-DOC is composed of relatively simple compounds which is more prone to be replaced from soil mineral surface and be utilized by microbes as opposed to Ho-DOC (Peuravuori et al., 2001). In Fig. 4, the man concentrations of Ho-DOC are much higher in SLM and PLM $\left(26.39 \pm 8.21\right.$ and $\left.22.51 \pm 6.07 \mathrm{mgl}^{-1}\right)$ than in DGM $\left(8.65 \pm 3.57 \mathrm{mgl}^{-1}\right)$ and the ditches $\left(6.20 \pm 3.01 \mathrm{mgl}^{-1}\right)$. But there is no remarkable dif25 ferences for Hi-DOC, which average values in all the sites focus mainly on the limited range from 5.59 to $9.29 \mathrm{mgl}^{-1}$. It is can be concluded that Ho-DOC takes the major part of DOC in SLM, PLM, while Hi-DOC takes precedence in the ditches. But in all the sites, Ho-DOC shows positive relation to total DOC significantly $(P<0.05)$.

5357

During the growing seasons, Ho-DOC shows different patterns between natural mires and other sites. In SLM and PLM, Ho-DOC concentrations exhibit unimodal curves with the apex occurring either in spring or summer. While in DGM and ditches, Ho-DOC decreases typically from spring to late August, and then abruptly rises in 5 early September, followed by a decline in mid-October. The $C_{V}$ value for Ho-DOC in the drainage ditches, 0.58 on the average, is much higher than that in the nautral and degraded mires with average of 0.44 and 0.33 , respectively, and there exists the same trend to Hi-DOC, which further reveals the significant response of DOC components to the ditches' hydrological regime after mire reclamation.

10 SUVA $_{254}$ has been suggested as an index of the aromaticity of DOC and indicates the most stable components in the dissolved carbons (Maurice and Leff, 2002). SUVA $_{254}$ values in the three landscapes show no clear fluctuation during the entire period with the mean $C_{\mathrm{V}}$ values reaching $0.14,0.18$ and 0.23 for the SLM and PLM, DGM, and the ditches, respectively (Fig. 5), which illustrates that the seasonal 15 change of temperature and hydrology only put relatively gentle influence on DOC aromatic characteristics. The mean seasonal SUVA $_{254}$ for SIM and PLM, $4.30 \pm 0.70$ and $4.45 \pm 0.49 \mathrm{Img}^{-1} \mathrm{~m}^{-1}$, are significantly larger than those of other sites. The mean SUVA 254 is $2.82 \pm 0.50 \mathrm{Img}^{-1} \mathrm{~m}^{-1}$ for DGM, and $2.00 \pm 0.42,2.20 \pm 0.60$, and $2.46 \pm 0.48 \mathrm{Img}^{-1} \mathrm{~m}^{-1}$ for C-DD, B-DD, and A-DD. The marked differences suggest that 20 aromatic carbon content of $\mathrm{DOC}$ is much lesser in degraded mires and ditches than in natural mires. Together with the dynamics of Ho- and Hi-DOC, the finding implies that mire reclamation results not only lower DOC concentration, but also decrease its stability in surface waters.

\subsection{Chemical composition analysis by EEMs}

25 The three-dimensional EEM fluorescence spectra of the water samples from the three landscapes in mid-summer (20 July) are illustrated in Fig. 6. Each EEM gives spectral information about the chemical compositions of DOC samples. In SLM and PLM, two 
main peaks can be clearly identified from the fluorescence spectra. The first main peak is located at the excitation/emission wavelengths (Ex/Em) of $335-340 / 435-440 \mathrm{~nm}$ (peak A), while the second peak is observed at the Ex/Em of 265-270/440-445 nm (peak B). Traditionally, peak A has been associated, in natural waters, with humic-like 5 organic substances which are usually composed of complex macromolecules, and the presence of this peak indicates the formation of humic acids during the composting process (Antízar-ladislao et al., 2006). In fact, there is a layer of humic soil, usually larger than $0.5 \mathrm{~m}$ in depth, under the plant litter layer in SLM and PLM, which ought to be the right reason to the clear peak of humic-like compounds. Peak B coincides

10 with peaks reported by Chen et al. (2003) typical of fulvic acid compounds. In comparison, the fluorescence intensities of peak A, about $1950 \mathrm{cps}$ in SLM and $2970 \mathrm{cps}$ in PLM, are 300-500 cps higher than peak B. Hence, in SLM and PLM, humic-like compounds are the predominant component in DOC, and fulvic acid is the other important component.

15 In DGM, the chemical compositions of DOC are remarkably different with SLM and PLM judged by the EEM fluorescence spectra (Fig. 6). Three peaks can be identified from the fluorescence spectra of DGM. The positions of the upper two peaks are very similar to peak A and B in SLM and PLM. One is related to humic-like substances with maximum fluorescence intensity of $1547 \mathrm{cps}$, while the other is the peak of fulvic 20 acid with the maximum flurescence intensity of $2152 \mathrm{cps}$. The third peak, whose upper shoulder links closely with peak B, emerges at the Ex/Em of 226-238/430-445 nm (peak C). According to the studies of Mopper and Schultz (1993) and Coble (1996), this peak $C$ belongs to the typical humic-like substances of freshwater in visible region. So, the two traditional humic-like peaks of terrestrial freshwater in UV and visible region are

25 both present in DGM, which are indicative of the most noticeable differences in DOC compositions between the DGM and SLM/PLM.

In the drainage ditches A-DD, B-DD and C-DD, there exists remarkable difference in the spatial distribution of main fluorescence peaks in comparison with SLM, PLM and DGM (Fig. 6). Three main peaks can be identified for all the ditches sites from

5359

their fluorescence spectra. The first peak emerges at the Ex/Em of 224-248/420$440 \mathrm{~nm}$ (peak C) which is located in the spectra range of humic-like substances like that in DGM. The second and the third peak for the ditches are located at the Ex/Em of 280/340-350 nm (peak T) and 220-225/340-350 nm (peak S), respectively. Peak T is

5 a protein-like peak which is associated with both macro-algal exudates (Parlanti et al., 2000) and bacterial activities from sewage- and agriculture-related organic pollution (Baker and Inverarity, 2004). Peak S ought to be tryoptophan-like substances in low excitation wavelengths according to the research of Wang et al. (2009). Tyrosine and tryptophan compounds are important biological substances with aromatic structure,

10 and traditionally, these peaks have been associated, in natural waters, with biological protein-derived compounds which indicate the presence of allochthonous pollution.

In all the ditches, although the fluorescence intensity of peak $C$ is much larger than peak $T$ and S, with the average values of 2733, 1845 and $1029 \mathrm{cps}$ accordingly, peak $T$ and $S$ are very conspicuous and independent to other peaks. In fact, peak $T$ also oc-

15 curs in the EEM of DGM, but its intensity is too weak to be focused on when compared to other three main peaks. Hence, DOC in the ditches is mainly composed of humic-like substances and biological substances, which is indicative of the basic discrepancy in DOC composition and source compared with DGM, SLM and PLM. Most compounds of DOC in the DGM, SLM and PLM mainly derive from direct decomposion of plant litter 20 and humic soil, while large part of DOC in the ditches comes from biological protein which had close relationship with agricultural activities in the catchment. Furthermore, from C-DD to A-DD, the intensity values of all the three peaks decrease gradually according to the ditches' hierarchy. For example, the intensity of peak $C$ is about $3010 \mathrm{cps}$ in C-DD, and declines to $2753 \mathrm{cps}$ in B-DD, and then $2430 \mathrm{cps}$ in A-DD, and the trend

25 is the same to peak $T$ and $S$. It ought to be the dilution effect by surface runoff that lead to the decrease, for the possibility of the quick decomposition of humic-like substances and biological substances in such a short distance from C-DD to B-DD, less than $5 \mathrm{~km}$, is considerably samll. Of course, the decomposition of DOC by microbe and UV light or the adsorption by mineral soil is sure to take effect to a certain degree. 
But more detailed researches are needed to reveal the degradation process of DOC components, as well as DIC, when transporting from the plain.

It is concluded that the chemical compositions of DOC in the three landscapes are clearly discrepant. In the natural mires, DOC is composed of humic-like organic sub-

5 stances and fulvic acid compounds, with similar composition to the degraded mire, while DOC compositions in the drainage ditches are mainly humic-like substances, protein- and tryptophan-like substances. Hence, mire reclamation has greatly altered the DOC composition with more biological substances exporting from the Sanjiang Plain, indicating a result of extensive agricultural pollution.

\section{Conclusions}

Concentrations of TC, DOC, and DIC, especially the chemical compositions of DOC, in the natural and degraded mires, and drainage ditches in the Sanjiang Plain are measured in the present research. A quality dataset will help in understanding the extensive alteration of the export dynamics of the dissolved carbons from the plain

15 after 50 years of successive mire reclamation. The presented results lead us to three major conclusions as follows: (1) a reduced loss of DOC and TC and an associated rise in the level of DIC in the degraded mires and artificial ditches are observed compared with those in natural mires. (2) A decreased stability of DOC in the degraded mires and ditches is found compared with the natural mires. (3) The chemical composition

20 of the DOC has greatly been altered with more biological substances in the ditches compared with natural and degraded mires. In total, the longterm mire reclamation has greatly declined DOC export concentration and chemical stability, and altered its chemical compositions in the Sanjiang Plain.

Acknowledgements. The work was supported by National Key Basic Research and Develop25 ment Projects (2009CB421103), National Natural Science Foundation of China (40930527), the Knowledge Innovation Program of the Chinese Academy of Sciences (KZCX2-YW-JC301),

5361

Strategic Priority Research Program - Climate Change: Carbon Budget and Related Issue of the Chinese Academy of Sciences, Grant No. XDA05020502, XDA05050508.

\section{References}

Aitkenhead, J. A. and McDowell, W. H.: Soil $\mathrm{C} / \mathrm{N}$ ratio as a predictor of annual riverine DOC flux at local and global scales, Global Biogeochem. Cy., 14, 127-138, 2000.

Antízar-Ladislao, B., Lopez-Reala, J., and Becka, A. J.: Investigation of organic matter dynamics during in-vessel composting of an aged coaltar contaminated soil using fluorescence excitation-emission spectroscopy, Chemosphere, 64, 839-847, 2006.

Atekwana, E. A. and Fonyuy, E. W.: Dissolved inorganic carbon concentrations and stable carbon isotope ratios in streams polluted by variable amounts of acid mine drainage, J. Hydrol., 372, 136-148, 2009.

Baker, A. and Inverarity, R.: Protein-like fluorescence intensity as a possible tool for determining river water quality, Hydrol. Process., 18, 2927-2945, 2004.

Bhatt, M. and Gardner, K.: Variation in DOC and tracemetal concentration along the heavily urbanized basin in KathmanduValley, Nepal. Environ. Geol., 58, 867-876, 2009.

Changnon, S. A. and Demissie, M.: Detection of changes in stream flow and floods resulting from climate fluctuations and landuse-drainage changes, Clim. Change., 32, 411-421, 1996.

Chen, W., Westerhoff, P., Leenheer, J. A., and Booksh, K.: Fluorescence excitation - emission matrix regional integration to quantify spectra for dissolved organic matter, Environ. Sci.

20 Technol., 37, 5701-5710, 2003.

Clair, T. A., Ehrman, J. M., and Higuchi, K.: Changes in freshwater carbon exports from Canadian terrestrial basins to lakes and estuaries under a $2 \times \mathrm{CO}_{2}$ atmospheric scenario, Global. Biogeochem. Cy., 13, 1091-1097, 1999.

Clark, J. M, Bottrell, S. H., Evans, C. D., Monteith, D. T., Bartlett, R., and Rose, R.: The importance of the relationship between scale and process in understanding long-term DOC dynamics, Sci. Total. Environ., 408, 2768-2775, 2010.

Coble, P. G.: Characterization of marine and terrestrial DOM in seawater using excitationemission matrix spectroscopy, Mar. Chem., 51, 325-346, 1996. 
Driscoll, C. T., Driscoll, K. M., Roy, K. M., and Mitchell, M. J.: Chemical response of lakes in the Adirondack Regionof NewYork to declines in acidic deposition, Environ. Sci. Technol., 37, 2036-2042, 2003.

Evans, C. D., Montieth, D. T., and Cooper, D. M.: Long-term increases in surface water dissolved

5 organic carbon: observations, possible causes and environmental impacts, Environ. Pollut., 137, 55-71, 2005.

Freeman. C., Evans, C. D., Montieth, D. T., Reynolds, B., and Fenner, N.: Export of organic carbon from peat soils, Nature, 412, 785-786, 2001.

Gao, H. and Zepp, R.: Factors influencing photoreactions of dissolved organic matter in a coastal river of the southeastern United States, Environ. Sci. Technol., 32, 2940-2946, 1998.

Goñi, M. A., Ruttenberg, K. C., and Eglinton, T. I.: A reassessment of the sources and importance of land-derived organic matter in surface sediments from the Gulf of Mexico, Geochim. Cosmochim. Acta., 62, 3055-3075, 1998.

Guo, Y. D., Wan, Z. M., and Liu, D. Y.: Dynamics of dissolved organic carbon in the mires in the Sanjiang Plain, Northeast China, J. Environ. Sci., 22, 84-90, 2010.

Hejzlar, J., Dubrovsky, M., Buchtele, J., and Ruzicka, M.: The apparent and potential effects of climate change on the inferred concentration of dissolved organic matter in a temperate stream (the Malse River, South Bohemia), Sci. Total. Environ., 310, 143-152, 2003.

Hernes, P. J., Spencer, G. M., Dyda, R. Y., and Pellerin, B. A.: The role of hydrologic regimes on

20 dissolved organic carbon composition in an agricultural watershed, Geochim. Cosmochim. Ac., 72, 5266-5277, 2008.

Holden, J., Chapman, P., and Labadz, J.: Articial drainage of peatlands: hydrological and hydrochemical process and wetland restoration, Prog. Phys. Geog., 28, 95-123, 2004.

Ittekkot, V.: Global trends in the nature of organic matter in the river suspensions, Nature, 332, 436-438, 1988.

Jonesa, T. G., Freeman, C., Lloyd, A., and Mills, G.: Impacts of elevated atmospheric ozone on peatland below-ground DOC characteristics, Ecol. Eng., 35, 971-977, 2009.

$\mathrm{Li}, \mathrm{W}$. Y., Fu, Q., and Zhao, Q.: Environment changes of analysis on the hydrographic and water resources of marsh wetland in the Sanjiang Plain, Res. Soil. Wat. Conserv., 14, 298-301, 2007 (in Chinese)

Mander, U., Kull, A., Kuusemets, V., and Tamm, T.: Nutrient runoff dynamics in a rural catchment: Influence of land-use changes, climatic fluctuations and ecotechnological measures, Ecol. Eng., 14, 405-417, 2000.

\section{3}

Moore, T. R., Roulet, N. T., and Waddington, J. M.: Uncertainty in predicting the effect of climatic change on the carbon cycling of Canadian peatlands, Clim. Change, 40, 229-245, 1998.

Mopper, K. and Schultz, C. A.: Fluorescence as a possible tool for studying the nature and water column distribution of DOC components, Mar. Chem., 41, 229-238, 1993.

5 Ortega, T., Ponce, R., Forja, J., and Go!amez-Parr, A.: Fluxes of dissolved inorganic carbon in three estuarine systems of the Cantabrian Sea (north of Spain), J. Mar. e Syst., 53, 125-142, 2005.

Parlanti, E., Worz, K., Geoffroy, L., and Lamotte, M.: Dissolved organic matter fluorescence spectroscopy as a tool to estimate biological activity in a coastal zone submitted to anthropogenic inputs, Org. Geochem., 31, 1765-1781, 2000.

Pastor, J., Solin, J., Bridgham, S. D., Updegraff, K., Harth, C., Weishampel, P., and Dewey, B.: Global warming and the export of dissolved organic carbon from boreal peatlands, Oikos, 100, 380-386, 2003.

Peichl, M., Moore, T. R., Arain, M. A., Dalva, M., Brodkey, D., and Joshua, M.: Concentrations and fluxes of dissolved organic carbon in an age-sequence of white pine forests in Southern Ontario, Canada, Biogeochemistry, 86, 1-17, 2007.

Raastad, I. A. and Mulder, J.: Dissolved organic matter (DOM) in acid forest soils at Gardsjon (Sweden): natural variabilities and effects of increased input of nitrogen and of reversal of acidification, Water. Air. Soil. Poll., 114, 199-219, 1999.

20 Raymond, P. A., Bauer, J. E., and Cole, J. J.: Atmospheric $\mathrm{CO}_{2}$ evasion, dissolved inorganic carbon production, and net heterotrophy in the York River estuary, Limnol. Oceanogr., 45, 1707-1717, 2000.

Simonsson, M., Kaiser, K., Danielsson, R., Andreux, F., and Ranger, J.: Estimating nitrate, dissolved organic carbon and DOC fractions in forest floor leachates using ultraviolet absorbance spectra and multivariate analysis, Geoderma, 124, 157-168, 2005.

Singh, S., D'Sa, E., and Swenson, E. M.: Chromophoric dissolved organic matter (CDOM) variability in Barataria Basin using exitation-emission matrix (EEM) fluorescence and parallel factor analysis (PARAFAC), Sci. Total. Environ., 408, 3211-3222, 2010.

Tang, L. H., Yang, D. W., Hu, H. P., and Gao, B.: Detecting the effect of land-use change on streamflow, sediment and nutrient losses by distributed hydrological simulation, J. Hydrol., 409, 172-182, 2011.

Tranvik, L. J. and Jansson, M.: Terrestrial export of organic carbon, Nature, 415, 861-862, 2002 
Tuengeun, O., Sandford, R. C., Jakmunee, J., Grudpan, K., Mckelvie, I., and Worsfold, P.: Determination of dissolved inorganic carbon (DIC) and dissolved organic carbon (DOC) in freshwaters by sequential injection spectrophotometry with on-line UV photo-oxidation, Anal. Chim. Acta., 554, 17-24, 2005.

5 Vitousek, P., Mooney, H., Lubchenco, J., and Melillo, J.: Human domination of earth's ecosystems, Science, 277, 494-499, 1997.

Wagner, L. E., Vidon, P., Tedesco, L. P., and Gray, M.: Stream nitrate and DOC dynamics during three spring storms across land uses in glaciated landscapes of the Midwest, J. Hydrol., 362, 177-190, 2008.

10 Wallage, Z. E., Holden, J., and McDonald, A. T.: Drain blocking: an effective treatment for reducing dissolved organic carbon loss and water discolouration in a drained peatland, Sci. Total. Environ., 367, 811-821, 2006.

Wang, J. T., Guan, H. S. G. W., Zhao, W. H., and Wang, X. L.: Fluorescence characterization of dissolved organic matter in East China Sea, Spectrosco. Spectr. Analysis., 29, 1345-1348, 2009 (in Chinese).

Wang, L. L., Song, C. C., and Song, Y. Y.: Effects of reclamation of natural wetlands to a rice paddy on dissolved carbon dynamics in the Sanjiang Plain, Northeastern China, Ecol. Eng., 36,1417-1423, 2010.

Williamson, C. E., Stemberger, R. S., Morris, D. P., Frost, T. M., and Paulsen, S. G.: Ultraviolet radiation in North American lakes: attenuation estimates from DOC measurements and implications for plankton communities, Limnol. Oceanogr., 41, 1024-1034, 1996.

Wilson, H. F. and Xenopoulos, M. A.: Effect of agricultural land use on the decomposition of fluvial dissolved organic matter, Nat. Geosci., 2, 37-41, 2009.

Worrall, F. and Burt, T. P.: The effect of severe drought on the dissolved organic carbon (DOC) concentration and flux from British rivers, J. Hydrol., 361, 262-274, 2008.

Worrall, F., Gibson, H. S., and Burt, T. P.: Produnction vs solubility in controlling runoff of DOC from peat soils-The use of an event analysis, J. Hydrol., 358, 84-95, 2008.

Yallop, A. R. and Cluterbuck, B.: Land management as a factor controlling dissolved organic carbon release from upland peat soils 1: Spatial variation in DOC productivity, Sci. Total. Environ., 407, 3803-3813, 2009.

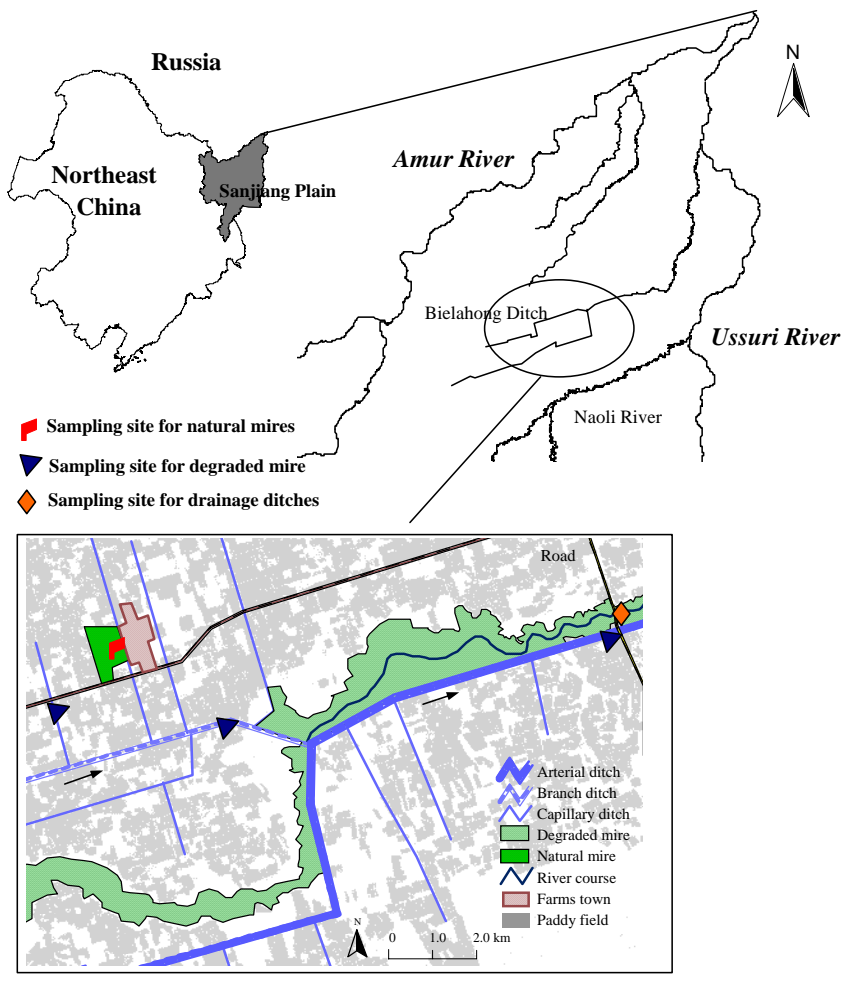

Fig. 1. Map of the sampling sites for the natural mires, degraded mires and drainage ditches in the Sanjiang Plain, Northeast China. 


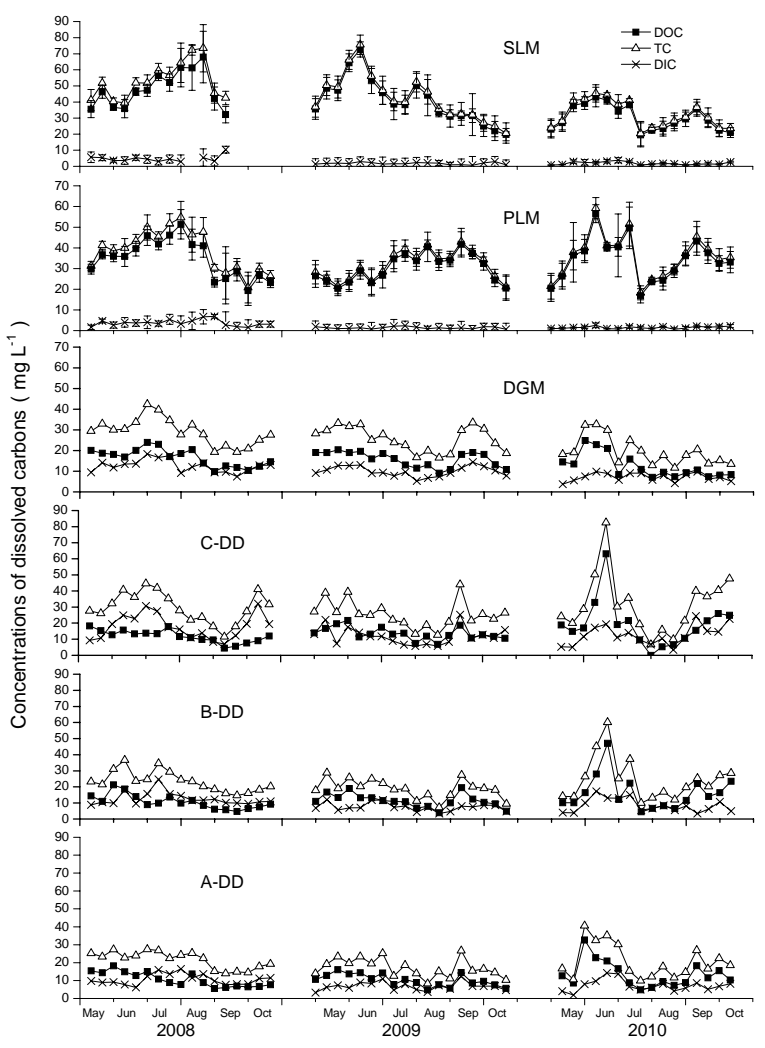

Fig. 2. Dynamics of the dissolved carbons in the natural, degraded mires and the ditches during the study period from 2008 to 2010 .

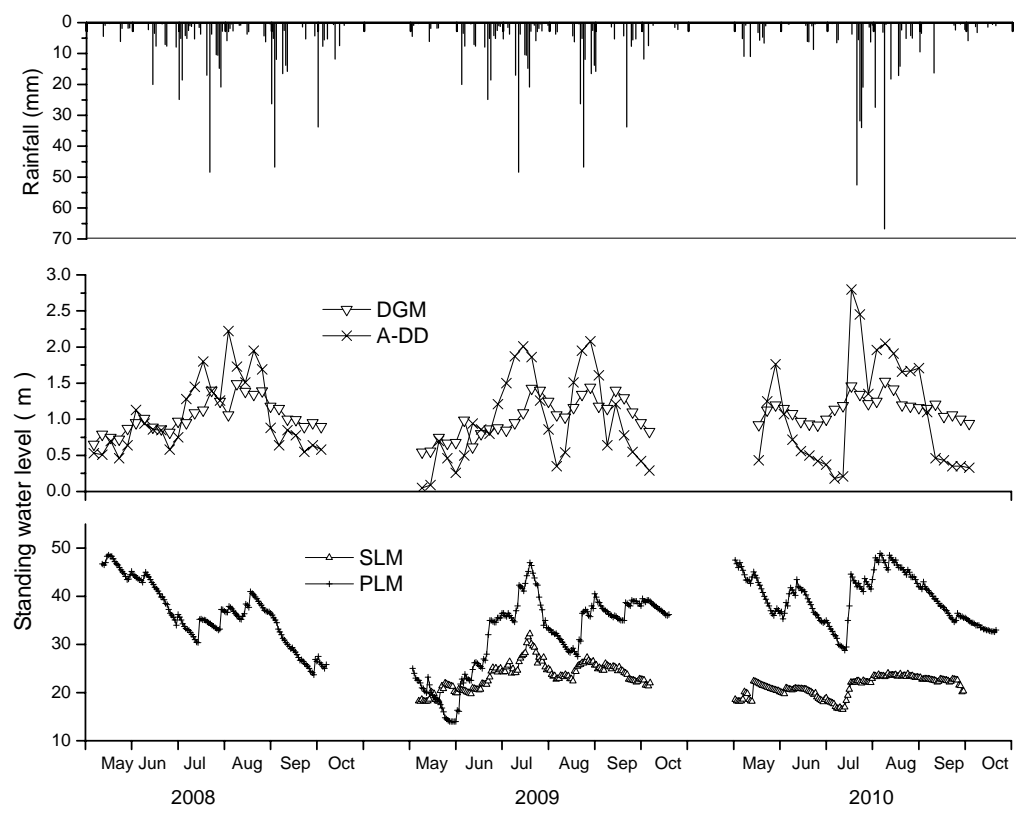

Fig. 3. The rainfall and standing water levels in the main sites during the study period from 2008 to 2010. 

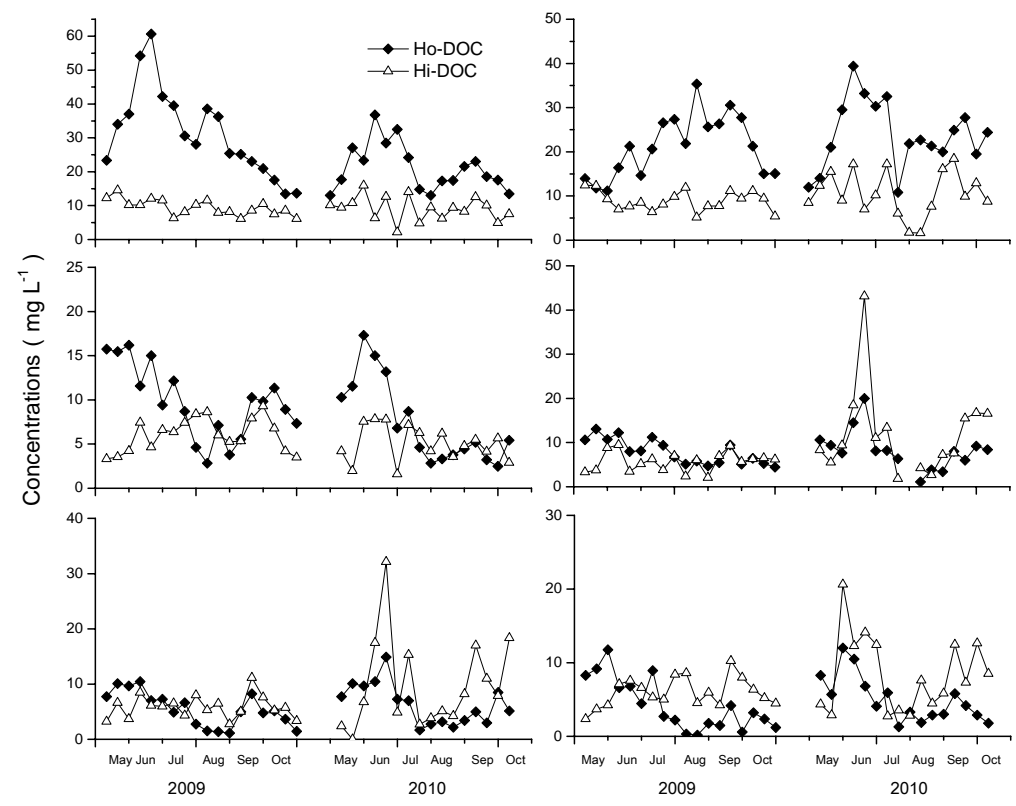

Fig. 4. DOC fractionation for the three landscapes during the study period in 2009 and 2010.

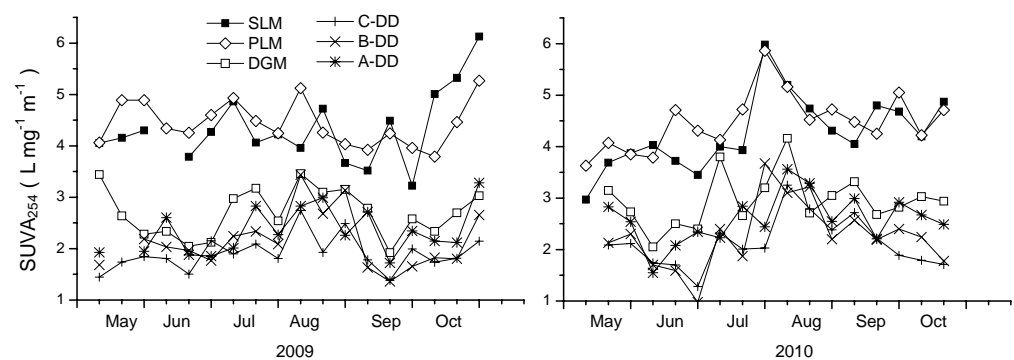

Fig. 5. SUVA 254 values of DOC for the three landscapes during the growing period in 2009 and 2010. 


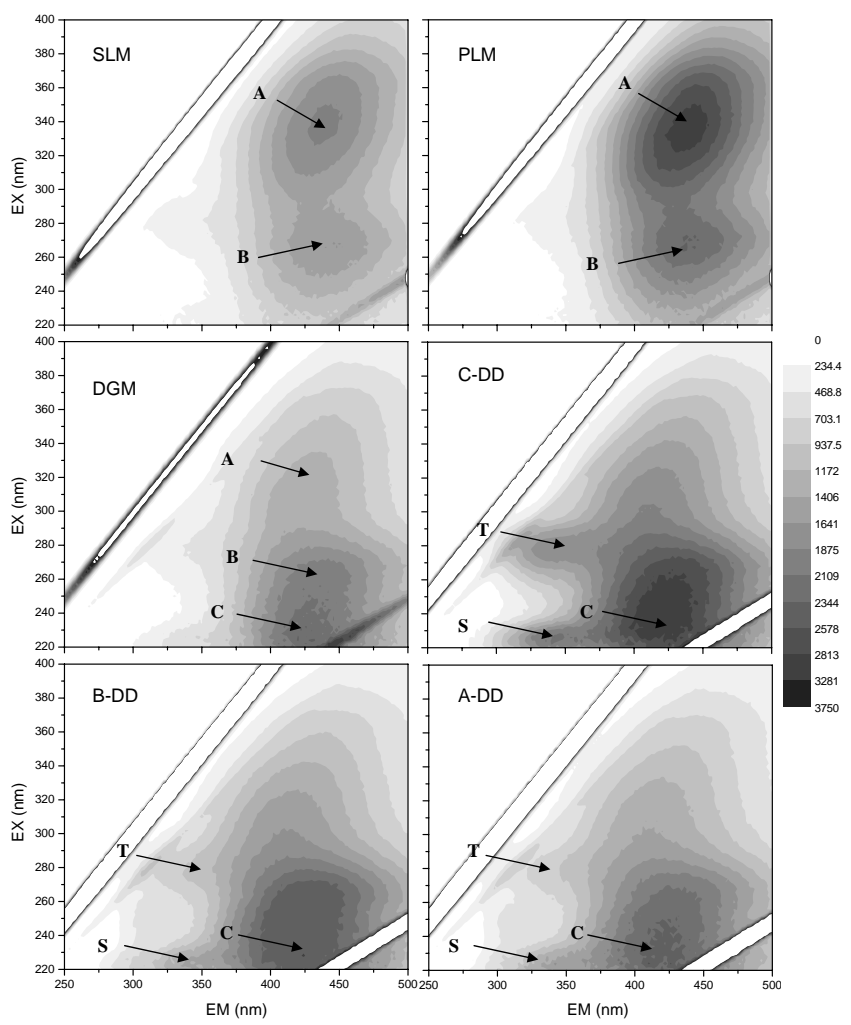

Fig. 6. Excitation-emission matrix (EEM) spectra for the water samples on 20 July in the three landscapes. 